\title{
Understanding the consequences of land use changes on sustainable river basin management in the Pacific Northwest, USA
}

\author{
M. M. Hasan ${ }^{1}$, M. E. Barber ${ }^{1}$, R. Goel ${ }^{1}$ \& R. L. Mahler ${ }^{2}$ \\ ${ }^{I}$ Civil and Environmental Engineering, University of Utah, USA \\ ${ }^{2}$ Soil Science Division, University of Idaho, USA
}

\begin{abstract}
Bioenergy is necessary to meet future world-wide energy demands while helping to offset the global impacts of increased carbon dioxide from traditional fossil fuels. Options for producing bioenergy without adversely impacting food, water, and other environmental resources include using woody biomass as feedstock. Key issues include soil, water quality and loss of biodiversity as collecting smalldiameter woody biomass may alter post-timber harvesting landscapes. Little is known about how land use changes impact the entire ecological function of the watershed. This project explored using changes in microbial soil populations as a function of woody biomass removal treatment scenarios to determine potential changes in long-term water export and nutrient ecology. This will help us understand the impacts of biomass removal in the production of jet fuel and be the start of holistic river basin management strategies focused on hydrologic implications of the entire food web.

Microbial population data were collected from 28 one acre plots subject to different land treatments and statistically analyzed to evaluate a null hypothesis that changes in biomass removal do not impact subsurface environment. Results indicate that significant removal of biomass is possible without statistically altering the microbial food web. Longer term analysis of soil infiltration and site runoff are needed to quantify the role of climate condition on these findings.
\end{abstract}

Keywords: anthropogenic case, ecological impacts, water quantity, evapotranspiration, infiltration, biomass removal. 


\section{Introduction}

Linkages between land use changes and runoff, erosion, and sedimentation processes in river basins are known to exist but little is known about how land use changes impact the entire ecological function of the watershed [1,2]. A potentially significant source of land use change in watersheds involves the production of bioenergy. Sustainable bioenergy production is necessary to meet future worldwide energy demands while helping to offset the global impacts of increased carbon dioxide from fossil fuels [3-6]. However, major concerns have been raised regarding the sustainability of energy crops due to environmental, watershed, and social issues $[7,8]$. The overarching goal of this study is to investigate the use of microbial population differences as indicators of potential watershed impacts of land use change due to residual ground cover (biomass) removal in the production of biofuel in the Pacific Northwest. This unique process would holistically examine potential long-term changes to watershed function in terms of ecosystem management as measured by changes in the food web indicated by early changes in microbial soil populations.

\section{Background}

One option for producing bioenergy minimizing adverse impacts to watershed functions and food production is using surplus forestry materials (woody biomass $[5,9])$. Key issues among stakeholders include impacts to soil and water quality, loss of watershed biodiversity, and climate implications. As part of NARA (Northwest Advanced Renewables Alliance), a broad alliance of private industry and educational institutions, this study focuses on the developing a novel early warning system using changes in microbial communities as an indicator of potential hydrologic/environmental concerns.

A trademark of most soil microbial communities is genetic diversity. For example, bacteria alone account for several thousand distinct genomes in a single gram of soil [10]. A study at Weyerhaeuser's Long-Term Soil Productivity (LTSP) sites indicated that severe soil compaction had no effect on community size or activity at subtropical or Mediterranean type sites and bacterial community structure and carbon utilization were similar between the reference stand and LTSP plantation. These results suggested land use changes as a result of forest harvesting did not have much impact on bacteria which agrees with several studies those found that clear-cutting either increases or has no effect on bacterial size and function $[11,12]$.

The objectives of this study was to collect and examine microbial communities at the test plots to find out the effect of removing biomass from the field in microbial level specifically if there is any significant change in bacterial community structure indicating potential long-term implications to nutrient dynamics. Based on this objective our null hypothesis is that there will be no changes in microbial community and our alternative hypothesis is that changes in soil moisture as a result of biomass removal may impact microbial community. 


\section{Methodology}

As part of Weyerhaeuser's effort to manage its more than six million acres of forested timberland in the US, it continues to conduct, evaluate, and support research associated with the North American LTSP program [13]. A new LTSP site near Springfield, OR was created to help support the Northwest Advanced Renewables Alliance project. A total of 28 one-acre plots were selected to aid in this investigation and round out an existing regional study, extending into warmer and drier parts of the Douglas-fir ranges. The treatment plots were laid out such that any plot could feasibly receive any treatment randomly assigned to it. As illustrated in Figure 1, all study plots were laid in on a $9^{\circ}$ azimuth to match site topography and simplify plot installation. These plots were not an individual subbasins for hydrologic analysis but rather part of a larger interconnected network. The study site is between 2000 and 2150 feet in elevation on gentle slopes of 2 to $20 \%$. The soil is mainly silty clay loam with some percentage of cobbly loam consists of three hydrologic soil category C, B and D with an average of $35 \%$ sand, $50 \%$ silt and $15 \%$ clay.

Seven different treatment combinations were applied to the study plots; 4 plots of each treatment. Figure 2 illustrates land use changes. The treatment combinations are categorized as follows:

A No Compaction Bole Only - Bole only harvest to a saw log top (5" top) all limbs and tops remain on the site. No ground trafficking.

B No Compaction Total Tree - Whole-tree type harvest where $\sim 75+\%$ of $\mathrm{limb} /$ top material is removed along with the bole. Remaining material will be dispersed. No ground trafficking.

C Compaction Bole Only - Bole only harvest to a saw log (5”) top - all limbs and tops remain across the whole site. Fixed traffic lanes.

D/F Compaction Total Tree - Whole-tree type harvest where $\sim 75+\%$ of $\mathrm{limb} /$ top material is removed along with the bole. Remaining material will be dispersed and equal across like plots. Fixed traffic lanes.

E/G Compaction Total Tree + FF - Whole-tree type harvest where $\sim 90-95 \%$ of $\mathrm{limb} /$ top material is removed along with the bole. Forest floor and legacy woody debris also removed. Compaction on this treatment will be the baseline for all compaction treatments.

Soil samples were collected in May 2014 from LTSP plots to perform DNA extraction test in the laboratory. Nine samples were collected from each plot. The samples were taken at a depth of 0-20 cm using a hand shovel. Rubber gloves were used at the time of collecting soil samples and the shovel was always cleaned properly after taking samples from every location. The soil samples were kept in 8 -ounce, air tight jars and were preserved in coolers at a temperature of less than $4^{\circ} \mathrm{C}$ to keep the microbial community safe. Dry ice was used to maintain the temperature of the coolers. A total of 252 samples from the LTSP plots and four samples from an unharvested plot were collected for subsequent DNA Extraction testing in the laboratory. 


\section{NARA LTSP - Treatments}

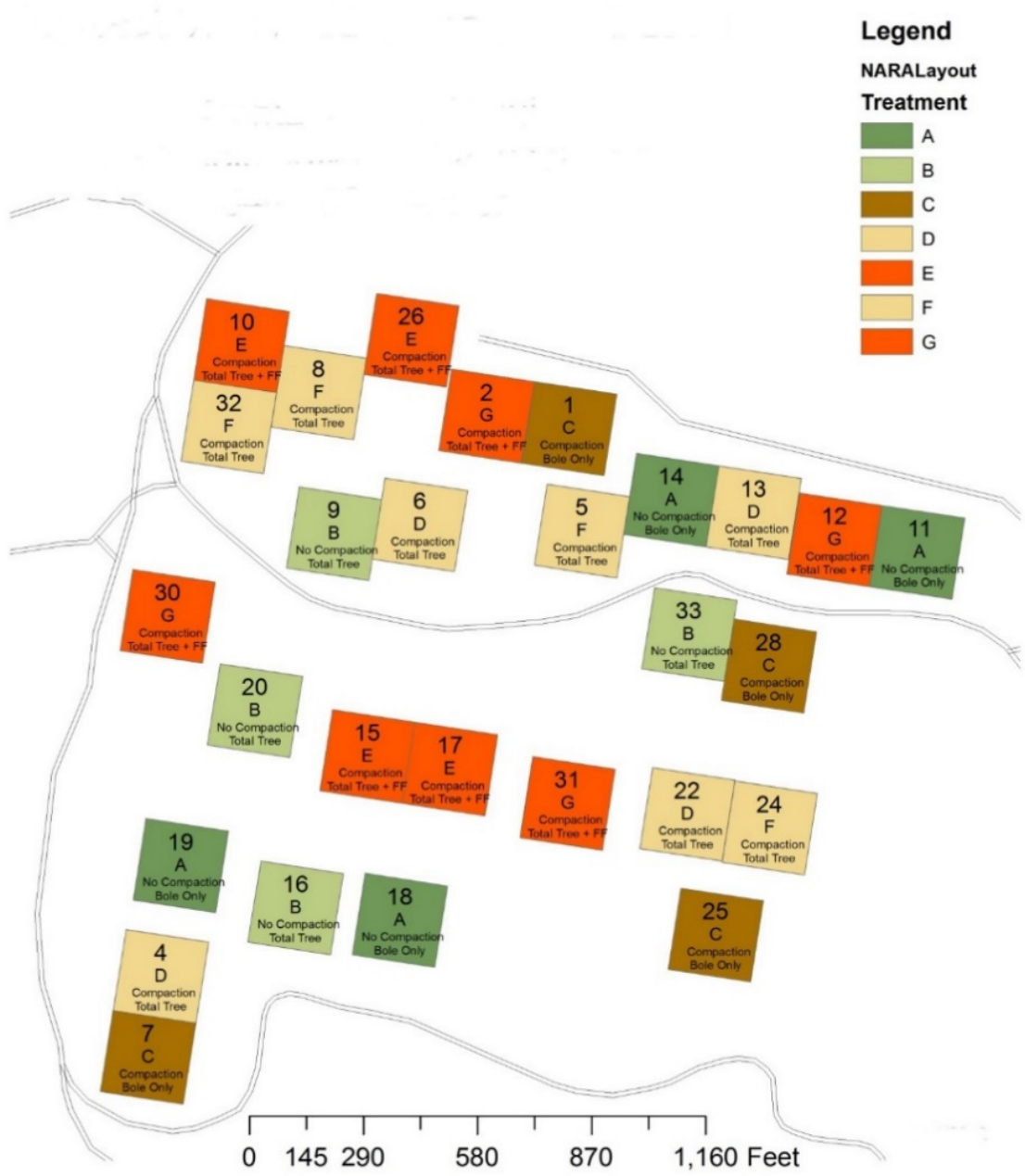

Figure 1: LTSP study plots and treatment combinations.

Different methods have been published for extracting DNA from soil [14-17] with a variety of procedures which are laborious, time-consuming and not suited for processing large numbers of samples [18]. Among the commercial DNA extraction kits, the highest A260/A230 ratios as well as the cleanest DNA, was provided by the Power Max or Power Soil kits depending on the soil but the higher yield of the Power Soil isolation kit than the Power Max kit makes the previous one a better choice in terms of providing the greatest amount of high-quality DNA [19]. 

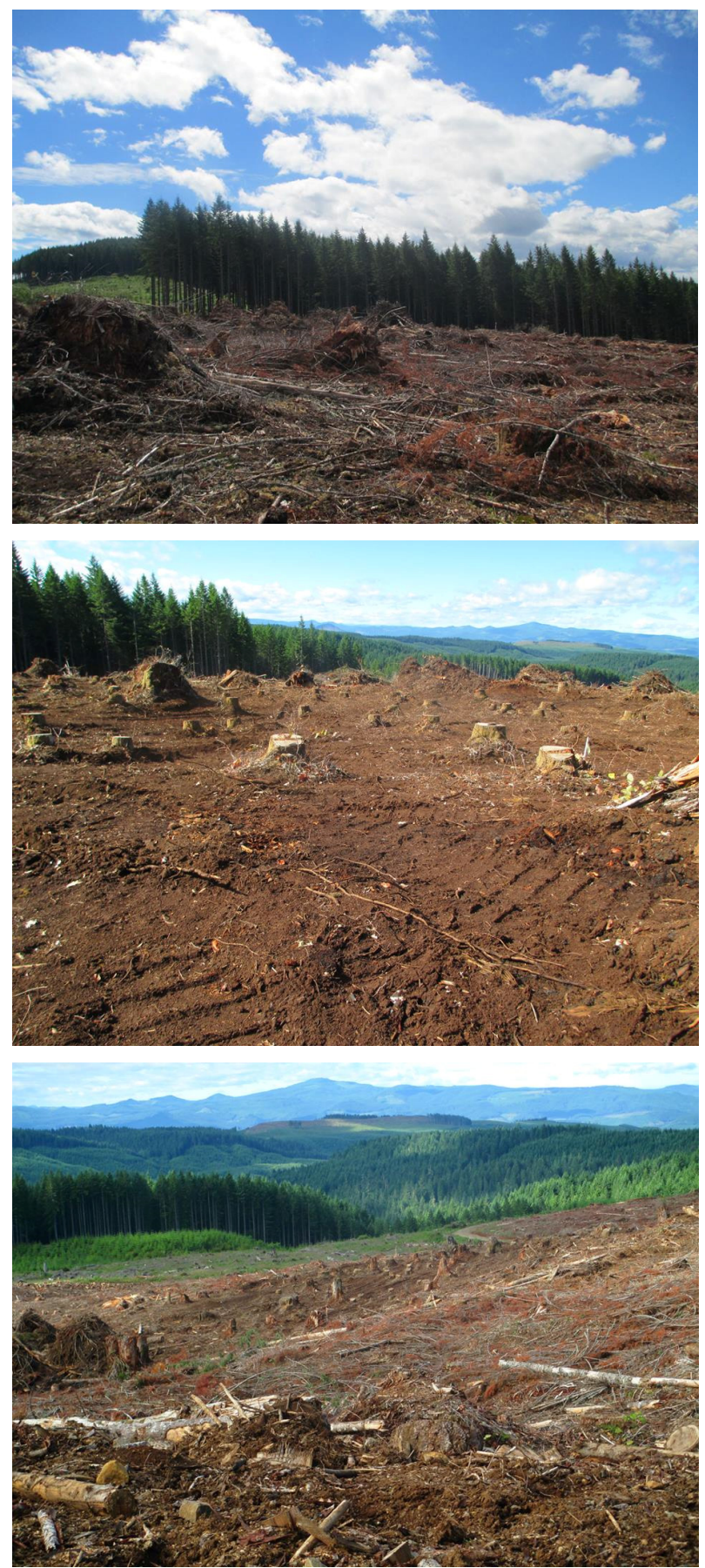

Figure 2: $\quad$ Land use change at NARA LTSP plots in Springfield, OR. 
MO Bio's Power Soil DNA isolation kit was used in the laboratory to extract DNA from the collected soil samples. Four DNA extraction test for each soil sample i.e. 144 for each treatment and 16 for the control one, concluding a total of 1024 test has been performed. MO BIO has developed a standard protocol to extract DNA from any soil using this kit which has been followed in this analysis. According to the protocol $0.25 \mathrm{~g}$ soil was taken from each 8 -ounces jar of soil samples and then six different solutions were used in different stages of the experiment. After isolating the DNA following the above protocol, a Nano Drop 2000c Spectrophotometer was used to measure the concentration of DNA. Before using the Nano drop meter it was cleaned by using sterile DNA-free PCR Grade water. A blank test was also run to make sure that there was no DNA. After running the blank test a drop of $2 \mu 1$ was put on the tiny small hole of the spectrophotometer. Then the lid of the meter was put down. A software has already been installed in the connecting computer named Nano drop software which calculated the concentration of DNA in $\mathrm{ng} / \mu \mathrm{l}$.

Forty samples out of 1024 DNA samples, 5 from each treatment including the control one has been selected for the finger printing analysis, in such a way so that those can be considered as the representative sample for each treatment. Community fingerprinting is used to profile the diversity of microbial community. These techniques show how many variants of a gene are present instead of counting individual cells in a sample. Though community fingerprinting presents an overall picture of a microbial community instead of identification of individual microbe species but still it is used to measure biodiversity or track changes in community structure. DNA fingerprinting allows the rapid assessment of the genetic structure of complex communities in diverse environments [20] and of the extent of changes caused by environmental disturbances [21, 22]. There are different types of fingerprinting technique among which the two most common techniques are i) T-RFLP (Terminal restriction fragment length polymorphism) and ii) ARISA (Automated ribosomal intergenic spacer analysis).

ARSIA samples were prepared from this PCR samples by following the protocol given below: $25 \mu \mathrm{l}$ of filtered sterilized DI (nuclease-free) water was added to each $20 \mu \mathrm{l}$ of PCR product. Then $10.0 \mu \mathrm{L}$ formamide (thawed from $-20^{\circ} \mathrm{C}$ ) was dispensed into the 96 well plate. $1.0 \mu \mathrm{L}$ of diluted PCR product was then added to the formamide dispensed into the well plates. After sealing with adhesive film and wrapping in aluminum foil, the plate was submitted to the genomic core facilities lab for running ARISA. Internal standard dye (ROX) was added to the samples by core facilities lab.

\section{Results and discussion}

MO Bio's Power Soil DNA isolation kit was used in the laboratory to extract DNA from the collected soil samples. Results of the DNA extraction tests are summarized in Table 1. 
Table 1: Results of DNA extraction tests for the LTSP sites.

\begin{tabular}{|c|c|c|c|}
\hline & Treatments & Plot Number & $\begin{array}{l}\text { Average DNA } \\
\text { Concentrations } \\
(\mathrm{ng} / \mathrm{ul})\end{array}$ \\
\hline A & No Compaction Bole Only & $\begin{array}{l}11 \\
14 \\
18 \\
19\end{array}$ & $\begin{array}{l}29.06 \\
51.84 \\
12.08 \\
37.14\end{array}$ \\
\hline $\mathrm{B}$ & $\begin{array}{c}\text { No Compaction Total Tree } \\
\text { Removal }\end{array}$ & $\begin{array}{c}9 \\
16 \\
20 \\
33\end{array}$ & $\begin{array}{l}37.85 \\
31.75 \\
63.77 \\
20.69\end{array}$ \\
\hline $\mathrm{C}$ & Compaction Bole Only & $\begin{array}{c}1 \\
7 \\
25 \\
28\end{array}$ & $\begin{array}{l}56.40 \\
38.48 \\
20.27 \\
45.84\end{array}$ \\
\hline $\mathrm{D}$ & $\begin{array}{c}\text { Compaction Total Tree } \\
\text { Removal }\end{array}$ & $\begin{array}{c}4 \\
6 \\
13 \\
22\end{array}$ & $\begin{array}{l}33.08 \\
24.70 \\
35.14 \\
21.49\end{array}$ \\
\hline $\mathrm{E}$ & $\begin{array}{c}\text { Compaction Total Tree + } \\
\text { Forest Floor }\end{array}$ & $\begin{array}{l}10 \\
15 \\
17 \\
26\end{array}$ & $\begin{array}{l}14.64 \\
20.35 \\
23.19 \\
28.92\end{array}$ \\
\hline $\mathrm{F}$ & Compaction Total Tree & $\begin{array}{c}5 \\
8 \\
24 \\
32\end{array}$ & $\begin{array}{l}49.06 \\
19.31 \\
27.51 \\
30.07\end{array}$ \\
\hline G & $\begin{array}{c}\text { Compaction Total Tree }+ \\
\text { Forest Floor }\end{array}$ & $\begin{array}{c}2 \\
12 \\
30 \\
31\end{array}$ & $\begin{array}{l}27.60 \\
16.13 \\
28.32 \\
15.01\end{array}$ \\
\hline & No Treatment & Unharvested Site & 15.44 \\
\hline
\end{tabular}

The average DNA concentrations (ng/ $\mu \mathrm{l})$ are different for different plots; even for those undergoing the same treatment process. For example, plot \#14 and plot \#18 both have the same treatment of "No Compaction - Bole Only" but the average DNA concentration is $51.84 \mathrm{ng} / \mu \mathrm{l}$ and $12.08 \mathrm{ng} / \mu \mathrm{l}$, respectively whereas considering plot \#19 and plot \#9 it has been found that the average DNA concentrations are $37.14 \mathrm{ng} / \mu \mathrm{l}$ and $37.85 \mathrm{ng} / \mu \mathrm{l}$ (although the treatment processes are different). We only recently completed the laboratory analysis so while the reason(s) behind this is not clear, we are still trying to find explanations by looking at soil types and variability. Four samples were taken from an unharvested control site where the average DNA concentrations is $15.44 \mathrm{ng} / \mu \mathrm{l}$. 
Two sample t-tests hypothesis testing has been performed to analyze the DNA extraction results and also to find out is there any correlation between the variation of DNA concentration and different treatments. Further analysis of the results of hypothesis testing will be done for more understanding.

A total of forty DNA samples, five from each treatment including the control one (unharvested site), have been analyzed using community fingerprinting analysis to find the diversity of microbial populations especially in the bacterial level. The analyses were completed to understand if there is any relation between the treatments and the diversity of microbial population. There are different methods for community fingerprinting out of which Automated Ribosomal Intergenic Spacer Analysis (ARISA) method will be followed in this case. Figures 3 and 4 graphically represent examples of the results for two different land disturbances (treatment types).

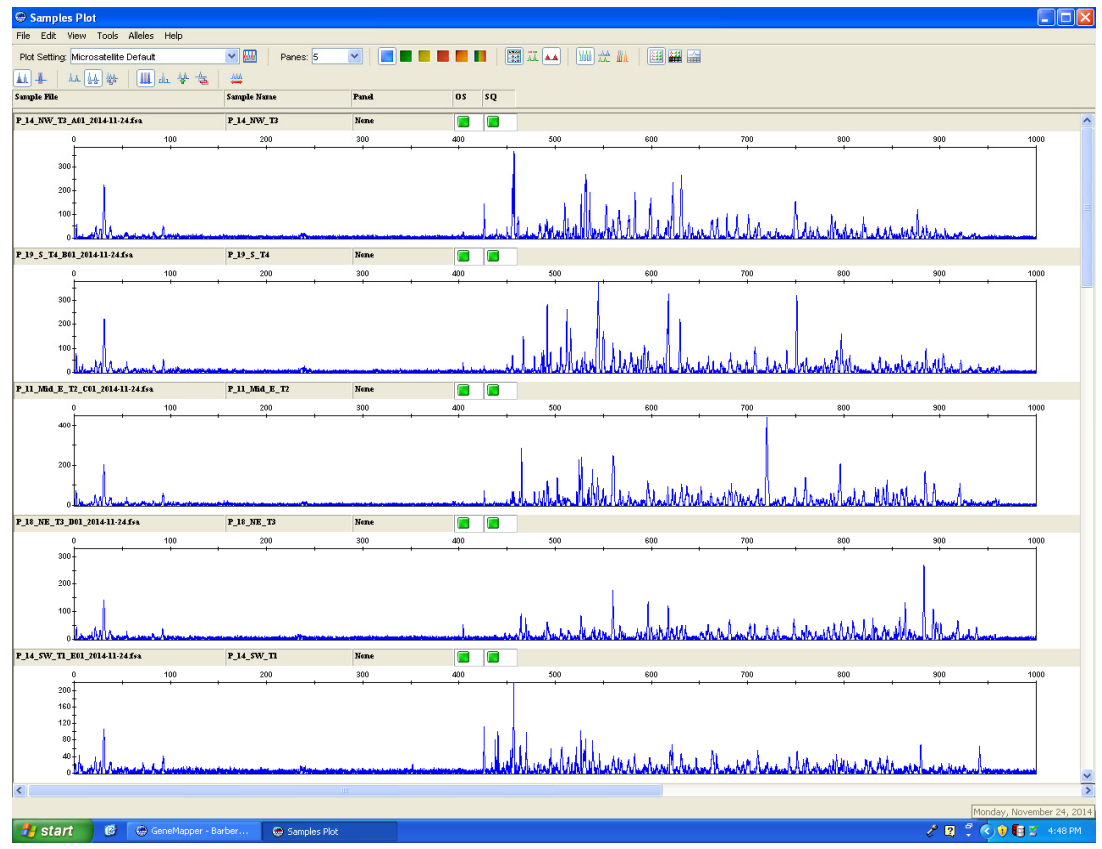

Figure 3: ARISA test run result for treatment A.

Each spike in the figure above a background level represents a different potential microbial community. The probability of the signal representing a community increases with the size of the spike (y-axis). Even in samples of the same treatment there are some obvious variations although patterns and trends do exist.

Statistical analysis of the data indicated only a few instances where significant $(\alpha=0.10)$ differences between treatments were observed. In these instances it was determined that there were fairly large Type II errors involved (accepting the null hypothesis when it is wrong). 


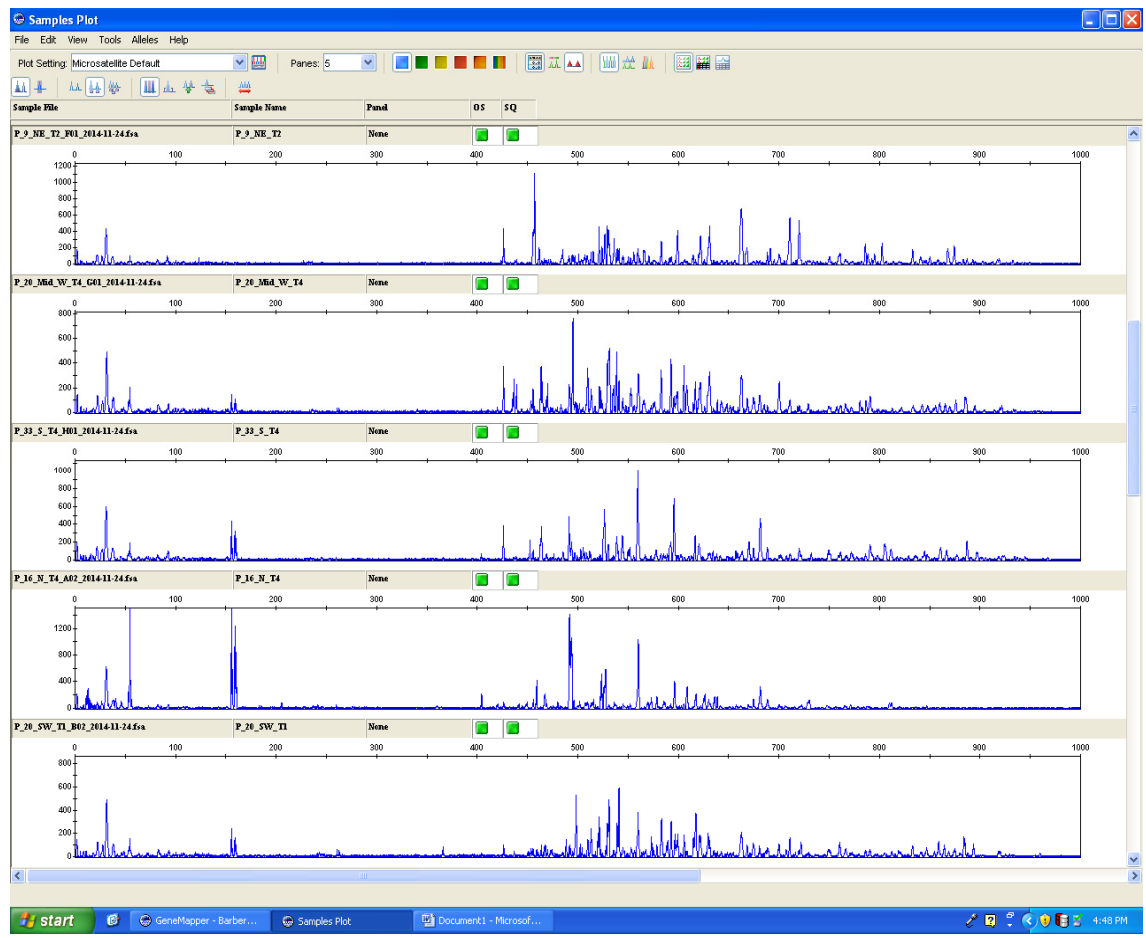

Figure 4: ARISA test run result for treatment B.

\section{Conclusions and recommendations}

Nine soil samples were collected from each of the 28 one acre sites and four DNA extraction test were performed for each sample for a total of 1008 data points. The average DNA concentration $(\mathrm{ng} / \mu \mathrm{l})$ per plot were developed based on the result of 36 DNA extraction tests for that plot. Analysis of average DNA concentrations did not show any statistically significant trends which would indicate that microbial variation due to different treatment processes is minimal and apparently nullify the hypothesis. This indicates that small diameter waste branches and other woody debris can be harvested without significant detrimental impact to the long-term flux of water and nutrients.

There is still a lot more work to do before this technique becomes a widely used method for understanding and managing land use in forested watersheds but this initial step is very promising. More analysis of the DNA extraction test data are required linked to water and nutrient fluxes. The ARISA results group different samples and representative DNA from each group will be further cloned and sequenced. We still need to use high throughput amplicon sequencing to exactly know the type of bacterial community in different treatment plots. This will allow us to answer the broad question "whether the indigenous community residing in soil change as a result of different treatment" More specifically, we will look for 
changes in bacteria responsible for nitrogen and phosphorus cycling- two nutrients of concern in any surface water quality efforts. In the end it will take a community effort to advance this important measure of watershed assimilation capacity.

\section{Acknowledgements}

This project was funded by the United State Department of Agriculture National Institute of Food and Agriculture. Our thanks also to Weyerhaeuser for making their LTSP site and climate data available for us to use.

\section{References}

[1] Walling, D.E., Linking land use, erosion and sediment yields in river basins, Man and River Systems, Developments in Hydrobiology, 146: 223-240, 1999.

[2] Hundecha, Y., and Bardossy, A., Modeling of the effect of land use changes on the runoff generation of a river basin through parameter regionalization of a watershed model, Journal of Hydrology, 292(1-4): 281-295, 2004.

[3] Berndes, G., Bioenergy and water-the implications of large-scale bioenergy production for water use and supply. Global Environmental Change, 12(4): 253-271, 2002.

[4] Johansson, D.J.A. and Azar, C., A scenario based analysis of land competition between food and bioenergy production in the US. Climatic Change, 82: 267-291, 2007.

[5] Beringer, T., Lucht, W. and Schaphoff, S., Bioenergy production potential of global biomass plantations under environmental and agricultural constraints. GCB Bioenergy, 3: 299-312, 2011.

[6] Aransiola, E.F., Ojumu, T.V., Oyekola, O.O., Madzimbamuto, T.F., IkhuOmoregbe, D.I.O., A review of current technology for biodiesel production: state of the art. Biomass and Bioenergy, 61(2): 276-297, 2014.

[7] Koh, L.P., and Ghazoul, J., Biofuels, biodiversity, and people: understanding the conflicts and finding opportunities. Biological Conservation, 141: 2450-2460, 2008.

[8] Searchinger, T.D., Heimlich, R., Dong, F., Elobeid, A., Fabiosa, J., Tokgoz, S. Hayes, D., and Yu, T.H., Use of U.S. croplands for biofuels increases greenhouse gases through emissions from land-use change. Science, 319: 1238-1540, 2008.

[9] Alavalapati, J. and Lal, P., Woody biomass fore energy: an overview of key emerging issues. Virginia Forests, p. 4-8. http://www.academia.edu/ 217032/Woody_Biomass_for_Energy_An_Overview_of_Key_Emerging_ Issues, 2009.

[10] Torsvik, V., Goksoyr, and Daae, F.L., High diversity in DNA of soil bacteria. Applied Environmental Microbiology, 56: 782-787, 1990.

[11] Lundgren, B., Bacteria in a pine forest soil as affected by clear-cutting. Soil Biol. Biochem, 14: 537-542, 1982. 
[12] Busse, M.D., Beattie, S.E., Powers, R.F., Sanchez, F.Z., and Tiarks, A.E., Microbial community responses in forest mineral soil to compaction, organic matter removal, and vegetation control, Canadian Journal of Forest Resources, 36, 2006.

[13] Ponder, Jr., F., Fleming, R.L., Berch, S. Busse, M.D., et al., Effects of organic matter removal, soil compaction and vegetation control on 10 th year biomass and foliar nutrition: LTSP continent-wide comparisons. Forest Ecology and Management, 278: 35-54, 2012.

[14] Smalla, K., Creswell, N., Mendonca-Hagler, L., Wolters, A., van Elsas, J., Rapid DNA extraction protocol from soil for polymerase chain reactionmediated amplification. Journal of Applied Bacteriology, 74: 78-85, 1993.

[15] Zhou, J., Bruns, M.A., Tiedje, J.M., DNA recovery from soils of diverse composition. Applied Environmental Microbiology, 62: 316-322, 1996.

[16] Krsek, M. and Wellington, E.M., Comparison of different methods for the isolation and purification of total community DNA from soil. Journal of Microbiology Methods, 39: 1-16, 1999.

[17] Hurt, R.A., Qiu, X., Wu, L., Roh, Y., Palumbo, A.V., and Tiedje, J.M., Simultaneous recovery of RNA and DNA from soils and sediments. Applied Environmental Microbiology, 6: 4495-503, 2001.

[18] Whitehousea, C.A. and Hottelb, H.E., Comparison of five commercial DNA extraction kits for the recovery of Francisella tularensis DNA from spiked soil samples. Molecular and Cellular Probes, 21: 92-96, 2007.

[19] Mahmoudi, N., Slater, G.F., and Fulthorpe, R.R., Comparison of commercial DNA extraction kits for isolation and purification of bacterial and eukaryotic DNA from PAH-contaminated soils, Canadian Journal of Microbiology, 57, 2011.

[20] Muyzer, G., and Smalla, K., Application of denaturing gradient gel electrophoresis (DGGE) and temperature gradient gel electrophoresis (TGGE) in microbial ecology. Antonie van Leeuwenhoek, 73: 127-141, 1998.

[21] Massol-Deya, A., Weller, R., Rios-Hernandez, L., Zhou, J.Z., Hickley, R.F., and Tiedje, J.M., Succession and convergence of biofilm communities in fixed-film reactors treating aromatic hydrocarbons in groundwater. Applied Environmental Microbiology, 63: 270-276, 1997.

[22] Engelen, B., Meinkein, K., von Wintzingerode, F., Heuer, H., Malkomes, H.P., and Backhaus, H., Monitoring impact of a pesticide treatment on bacterial soil communities by metabolic and genetic fingerprinting in addition to conventional testing procedures. Applied Environmental Microbiology, 64: 2814-2821, 1998. 